\title{
OPCML wt Allele
}

National Cancer Institute

\section{Source}

National Cancer Institute. OPCML wt Allele. NCI Thesaurus. Code C116961.

Human OPCML wild-type allele is located in the vicinity of $11 \mathrm{q} 25$ and is approximately $1117 \mathrm{~kb}$ in length. This allele, which encodes opioid-binding protein/cell adhesion molecule protein, plays a role in opioid receptor activity. Variation of the gene is associated with increased susceptibility to ovarian cancer. 